\title{
Cross-cultural adaptation, content validity index, and interobserver reliability of The SACSTM Instrument: Assessing and classifying peristomal skin lesion
}

\author{
Adaptação cultural, índice de validade de conteúdo e confiabilidade \\ interobservadores do The SACSTM Instrument: Assessing and classifying \\ peristomal skin lesion
}

\begin{abstract}
Adaptación cultural, índice de validez de contenido y confiabilidad interobservador

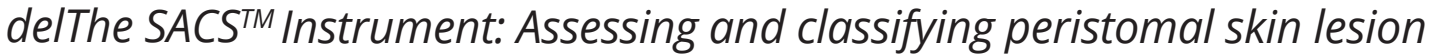

Néria Invernizzi Silveira ${ }^{1, *}$ Leni Boghossiam Lanza²

ORCID IDS

Silveira N (iD https://orcid.org/0000-0003-1677-4206
HOW TO CITE

Silveira Nl; Lanza LB (2019) Cross-cultural adaptation, content validity index, and interobserver reliability of The SACSTM Instrument: Assessing and classifying peristomal skin lesion. ESTIMA, Braz. J. Enterostomal Ther., 17: e1919. https://doi.org/10.30886/estima. v17.768_IN

\begin{abstract}
Objective: To adapt The SACS TM Instrument: assessing and classifying peristomal skin lesion to the Brazilian Portuguese language and to evaluate the Content Validity Index (CVI) and the interobserver reliability. Method: Methodological study with a quantitative approach. Two translators developed the cross-cultural adaptation for translation and two others for back-translation. The interobserver agreement was achieved by the analysis of 41 photographs by two enterostomal therapist nurses. Results: SACS ${ }^{\mathrm{TM}}$ obtained $\mathrm{CVI}=1$. The agreement for classification of lesions was $41.18 \%$ and $\mathrm{K}=0.2444$, for topographic location was $46.67 \%$ and $K=0.3151$, resulting in considerable and extremely significant agreement, with $p<0.001$. Conclusion: The study certified the version adapted to the Brazilian Portuguese language and attested that it requires the qualification of enterostomal therapists and generalist nurses in clinical practice.
\end{abstract}

DESCRIPTORS: Validation studies. Ostomy. Wounds. Lesions. Enterostomal therapy.

\footnotetext{
1.Universidade Estadual de Campinas - Faculdade de Enfermagem - Campinas/SP - Brazi

2.Pontifícia Universidade Católica de São Paulo - Faculdade de Ciências Médicas e da Saúde - Sorocaba/SP - Brazil

Correspondence author: E-mail: neriasilveira@gmail.com

Received: Jun. 03, 2019 | Accepted: Sept. 06, 2019
} 


\section{RESUMO}

Objetivo: Adaptar The SACSTM Instrument: assessing and classifying peristomal skin lesion para a língua portuguesa do Brasil e avaliar o Índice de Validade de Conteúdo (IVC) e a concordância interobservadores. Método: Estudo tipo metodológico com abordagem quantitativa. A adaptação cultural foi desenvolvida por dois tradutores para a tradução e outros dois para a retrotradução. A concordância interobservadores ocorreu pela análise de 41 fotografias por dois enfermeiros estomaterapeutas. Resultados: OSACS ${ }^{\mathrm{TM}}$ obteve IVC = 1 . A concordância para classificação das lesões foi de 41,18\% e $K=0,2444$, para localização topográfica foi 46,67\% e $K=0,3151$, resultando em concordância considerável e extremamente significante, com $p<0,001$. Conclusão: $O$ estudo atestou a versão adaptada para a língua portuguesa do Brasil e que necessita de capacitação dos enfermeiros estomaterapeutas e generalistas na prática clínica.

DESCRITORES: Estudos de validação. Estomia. Ferimentos. Lesões. Estomaterapia.

\section{RESUMEN}

Objetivo: Adaptar The SACS ${ }^{T M}$ Instrument: assessing and classifying peristomal skin lesion para Portugués brasileño y para evaluar el Indice de Validez de Contenido (IVC) y el acuerdo interobservador. Método: Estudio metodológico con enfoque cuantitativo. La adaptación cultural fue desarrollada por dos traductores para la traducción y otros dos para la traducción inversa. El acuerdo interobservador se produjo mediante el análisis de 41 fotografías realizadas por dos enfermeras estomatoterapeutas. Resultados: EI SACS TM obtuvo IVC = 1 . El acuerdo para la clasificación de la lesión 41,18\% y K = 0,2444, para la ubicación topográfica fue 46,67\% y K=0,3151, resultando em um acuerdo considerable y extremadamente significativo con $p<0,001$. Conclusión: El estudio atestiguó la versión adaptada a la lengua portuguesa de Brasil y que requiere la formación de enfermeras estomatoterapeutas y generalistas en la práctica clínica.

DESCRIPTORES: Estudios de validación. Ostomía. Lesión. Lesiones. Estomaterapia.

\section{INTRODUCTION}

The peristomal skin is defined by the $7.5 \mathrm{~cm}$ area of the entire stoma border. In the immediate postoperative period, the peristomal skin is intact, with the presence of natural microbiota and mucocutaneous suture. After a certain period, it also presents microbiota of intestinal origin in the epidermis and the hair follicle ${ }^{1-4}$.

Some factors predispose the appearance of peristomal skin lesions with various etiologies such as pre-existing diseases, exposures of elimination and care factors, including inadequate prescription or misuse of collection equipment $t^{5,6,7}$.

In a 2008 systematic review, Salvadalena identified 21 studies of peristomal skin lesions and concluded that there are differences between data collection studies, making the calculations for the incidence of these lesions incompatible in this surveys ${ }^{8}$.

In 2010, Beitz et al. concluded that the incidence of complications in peristomal skin is very variable, from 6.0 to $66.8 \%$, due to differences in terminology definitions, populations assessed, projects and length of study, presenting difficulties for comparisons between the studies?.

Because of the lack of a unified instrument, Bosio et al. created in 2006 the instrument SACS ${ }^{\mathrm{TM}}$, from the
Italian Studio Alterazioni Cutanee Stomali, which allows standardized evaluation, classification, and recording of peristomal skin lesions. Lesions are determined by the letter $\mathrm{L}$ followed by ordinal numbers, according to the damage to the skin layers. The location of the lesions is designated by the letter $\mathrm{T}$ followed by roman numerals, which are identified by the quadrants around the stoma, in a similar way to the breast cancer quadrants ${ }^{10}$.

In 2007, Bosio et al. ${ }^{11}$ selected 20 skin lesion images and the guideline to use SACS ${ }^{\mathrm{TM}}$, sending it to four specialists for the analysis of the Content Validity Index (CVI), which resulted in CVI $=0.91$, proving the agreement among the judges as very $\operatorname{good}^{11}$.

The SACS ${ }^{\mathrm{TM}}$ Instrument was applied by Beitz et al. ${ }^{9}$ and obtained the CVI $=0.94$, concluding that the descriptions of peristomal skin lesions are the same used internationally. The instrument contains clinical photos for the topographic location of the lesion and presents the quadrants around the stoma as clock-face orientation?.

The SACS ${ }^{\mathrm{TM}}$ Instrument has the appearance of a business card, with the classification of lesions on one side, assisted by photographs, and on the other side the topographic location in quadrants according to the clock face ${ }^{12}$. 


\section{OBJECTIVES}

To adapt The SACS ${ }^{\mathrm{TM}}$ Instrument: assessing and classifying peristomal skin lesion to the Brazilian Portuguese language and to evaluate the content validity index (CVI) and the interobserver reliability.

\section{METHODS}

This was a methodological study with a quantitative approach, which provided the organization and analysis of data for the stages of cross-cultural translation, CVI, and reliability of the instrument ${ }^{13}$.

The Ethics and Research Committee approved the project of the Pontifical University of São Paulo no. 1,759,293, and all ethical aspects were respected, complying with Resolution 466/2012, provided for research involving human beings. The participation of professionals was only initiated after the completion and signing of the informed consent form and the guarantee of anonymity.

The SACS ${ }^{\mathrm{TM}}$ Instrument has international authorization for use by ConvaTec Incorporation and national authorization by ConvaTec Brazil ${ }^{12}$.

The scientific research method followed a systematic and rigorous process for cross-cultural adaptation to Brazilian Portuguese. For the analysis of the measurement properties, the ICV and interobserver reliability were used. The steps in this process are translation, translation synthesis, back-translation, and back-translation synthesis. Back-translation is a requirement to fulfill the phases of scientific research for the cross-cultural translation of an instrument, to ensure that the translation from English into Portuguese has the same translation from Portuguese into English. The translator who makes the back-translation does not have access to the original English document ${ }^{13,14}$.

The instrument was used for the translation phase in its English version since the English language was considered as an international means of communication by English as a lingua franca (ELF) ${ }^{15,16}$.

The synthesis of the translation (T1 and T2) was the comparison between the different translations, and there were no difficulties to compile the final version from the translators $(\mathrm{FVT})^{13,14}$.
For the back-translation phase, the FVT was sent to two native English language translators (R1 and R2) $)^{14,15}$.

Subsequently, comparisons were made between the back translations (R1 and R2), which did not present difficulties in compiling the final version in Portuguese $(\mathrm{FVP})^{13,14}$.

The SACS ${ }^{\mathrm{TM}}$ and the FVP were evaluated by a committee of judges composed of seven enterostomal therapists with experience in the area of care to people with stomata. Five judges had an intermediate level of English, and two had an advanced level. The evaluated psychometric measurement property was CVI. The CVI measures the proportion of the number of concordant answers of the judges for each item of the instrument for the semantic equivalence (SE), which verifies the meaning of the word, vocabulary and grammatical correspondence; idiomatic equivalence (IE), the correspondence of expressions in the respective languages, especially the expressions that are difficult to translate; conceptual equivalence $(\mathrm{CoE})$, the appreciation of instrument concepts for the conceptions of the studied language; and crosscultural equivalence (CCS), which is the analysis of the different situations between the countries' cultures ${ }^{13,14}$.

The equivalences were presented in Likert scale with scores from 1 to 4 , in which 1 represents "not clear", 2 "clear", 3 "quite clear" and 4 "very clear"13.

The number of items defines the formula for the CVI scored 3 or 4 by the judges, divided by the number of all judges. The finding of IVC $\leq 0.75$ implies the automatic revision of the item since it means that at least one of the judges does not validate its content. Items that received scores 1 or 2 should have considerations made by the respective judge.

Eq. 1 represents the formula for calculating the $\mathrm{CVI}^{17}$.

CVI = (no. of answers " 3 " and " 4 ")/(Total no. of answers)

Based on the judges' considerations, the Portuguese version (PV) was obtained. The PV reliability was measured using the agreement that can occur between two or more interobserver. The statistical method used was the Kappa coefficient (K), which measures the proportion of expected and actual agreement. The result of $\mathrm{K}$ is classified as follows: if the value $\mathrm{K}=0$ it means that reliability is poor; if $\mathrm{K}=0 \leq 0.20$, slight; if $\mathrm{K}=$ $0.21 \leq 0.40$, considerable; if $\mathrm{K}=0.41 \leq 0.60$, moderate; 
if $\mathrm{K}=0.61 \leq 0.80$, substantial; if $\mathrm{K}=0.81 \leq 1.00$, excellent ${ }^{18-20}$.

Another statistical method used in this study to evaluate the reliability of the instrument was the level of statistical significance or probability of significance. This method has the definition of "probably true" which is represented by $\mathrm{p}$-level or $\mathrm{p}$. Its meaning is the probability of noncompatible interobserver answers, which is 5\%. The classification of values for the level of statistical significance is: $p>0.05$ which means that the value is not significant, between $0.01 \leq 0.05$ is significant, between $0.001 \leq 0.01$ is very significant and $p<0.001$ is extremely significant ${ }^{21}$.

The data were recorded and analyzed by software Stata from the company StataCorp.

\section{RESULTS}

The steps of translation, synthesis, and backtranslation were successfully obtained without difficulties.

The seven judges received two forms by e-mail, one containing the SACS ${ }^{\mathrm{TM}}$ items, the synthesis of translations, and the back-translations for evaluation of equivalences, and the other with instructions for completing the equivalence analysis, containing spaces for considerations of each item. The score presented by the judges resulted in CVI $=1$.

The judges presented qualitative comments regarding the concepts, such as changes in the term "lesão hiperêmica" to "byperemia"; the word "vermelhidão" to "eritema", because erythema is reddish and with intact skin; "tecido fibrinoso" to be changed to "esfacelo". In the L4 classification, they requested the addition of "lesão ulcerativa com tecido inviavel' and the use of the peristomal skin vocabulary. All suggestions have been respected.

Thus, the version adapted to Brazilian Portuguese presents the original instrument's image of skin lesions with the descriptions of peristomal skin lesions (Table 1), the topographic location in quadrants according to the clock face, and the recording form, as shown in Fig. 1.

The agreement occurred through the application of the adapted version for two interobserver enterostomal therapists. For this purpose, a file was prepared at software Microsoft PowerPoint containing guidelines for evaluation and classification of peristomal lesions,
Table 1. Adapted version of the SACS TM Instrument to Brazilian Portuguese.

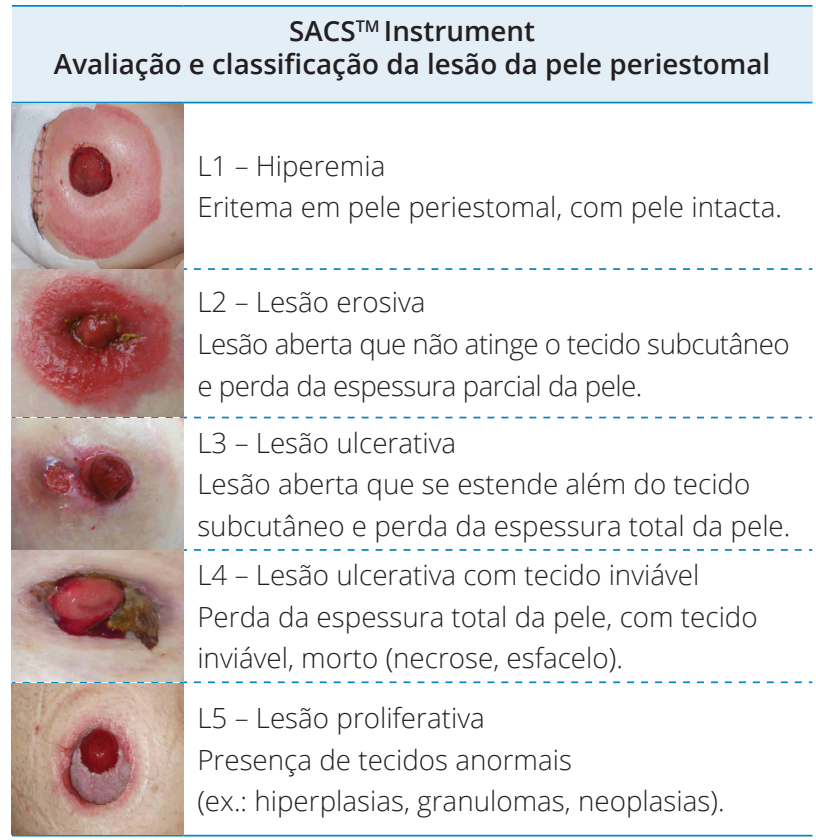

Head of person with ostomy

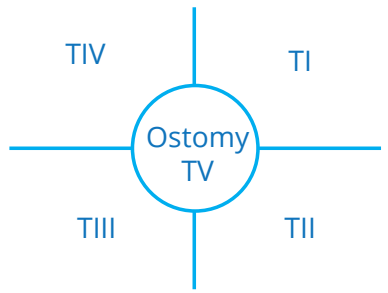

Feet of person with ostomy

TI: Upper left quadrant of the patient's peristomal skin (12 to 3 hours)

TII: Left lower quadrant of the patient's peristomal skin (3 to 6 hours)

TIII: Right lower quadrant

of patient's peristomal skin (6 to 9 hours)

TIV: Upper quadrant right of patient's peristomal skin (9 to12 hours)

TV: All squares of the periestomal area

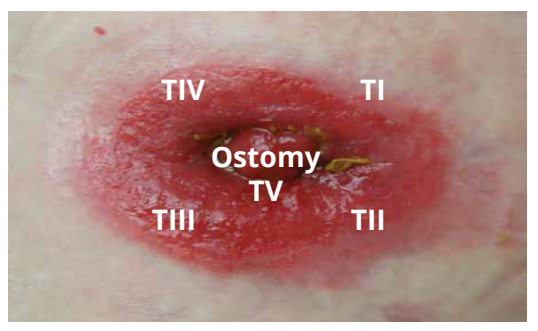

Figure 1. Example of a peristomal skin lesion in SACS $^{\text {TM }}$ (Classification SACS ${ }^{\mathrm{TM}}$ : L2 TV).. 
topographic location, recording type of the SACS ${ }^{\mathrm{TM}}$ Instrument, and 41 photographs of injured peristomal skin that could be zoomed in for the clarity of evaluations.

The interobserver 1 is a 39 -year-old female enterostomal therapist nurse, graduated in Nursing in 2002, with a specialization course in enterostomal therapy, completed a master's degree and has an ongoing doctorate in nursing diagnostics research line. The interobserver 2 is a female 41-years-old enterostomal therapist nurse, graduated in Nursing in 2007, with a specialization course in enterostomal therapy and master's degree in the area.

The result for the agreement ratio between peristomal skin lesions was $41.18 \%$ and $K=0.2444$; the agreement ratio for the topographic location was $46.67 \%$ and $\mathrm{K}=0.3151$; both resulting in considerable agreement levels. Regarding the level of statistical significance, the result was $\mathrm{p}<0.001$, i.e., an extremely significant level.

\section{DISCUSSION}

The methodology for the translation and validation of an instrument is an organized and important process. Literature for classification and topographic location and registration of peristomal skin lesion in Brazil, such as the $\mathrm{SACS}^{\mathrm{TM}}$ Instrument, is scarce.

The SACS ${ }^{\mathrm{TM}}$ presents consistent and uniform items, which did not present difficulties in the stages of translations and back-translations both in Brazil and Turkey ${ }^{22}$.

The evaluation of semantic, idiomatic, conceptual and cultural equivalences, both in Brazil and Turkey, resulted in $\mathrm{CVI}=1$, with approximate results in Italy with CVI $=0.91$ and in the United States with CVI $=0.94^{9,11,22}$.

The interobserver agreement occurred with two enterostomal therapist nurses. Both were trained to use the SACS ${ }^{\mathrm{TM}}$ Instrument with photographic images of peristomal skin lesions ${ }^{18-20}$.

The interobserver agreement occurred in 41 digitized photographs of peristomal skin lesions from the researcher's archive. The photographs were recorded with adequate illumination, in adults, with clean peristomal skin, without the collecting system, with the patient's initials, date, and cephalocaudal position. Photography and schematic drawings are used in the teaching/learning process, discussions, and interventions of clinical cases ${ }^{23}$.
Interobserver agreement between peristomal skin lesions was $41.18 \%$ and $\mathrm{K}=0.2444$; the topographic locations of the lesions were $46.67 \%$ and $\mathrm{K}=0.315$; resulting in considerable agreement.

In contrast, in the study conducted in Turkey ${ }^{22}$, the agreement was $95 \%$ and $\mathrm{K}=0.89$ for peristomal lesions; for topographic locations, it was $95 \%$ and $\mathrm{K}=0.88$, achieving excellent agreement. The interobserver in Turkey were eight enterostomal therapist nurses, subdivided into pairs. At the time of the study, all of them performed $80 \%$ of their activities with people with an ostomy, assisted on average 10 people with ostomy per week and had experience of $3.17 \pm 5.5$. The SACS ${ }^{\mathrm{TM}}$ Instrument was applied to 100 patients for 6 months (December 2012 to June 2013) per convenience sample ${ }^{23}$. One of the considerations due to differences in the agreement was that enterostomal therapist nurses did not work in the care of people with an ostomy.

Still, on the study conducted in Turkey ${ }^{22}, 85 \%$ of the interobserver stated that the SACS ${ }^{\mathrm{TM}}$ Instrument is practical and easy to use and considered it a facilitator for the care of peristomal skin lesions. Seventy-five percent reported that it was possible to determine the management of assistance by reducing costs and reducing overuse of products. The instrument SACS ${ }^{\mathrm{TM}}$ was important for recording, mainly because it had quick access to the evaluation card (credit card format), assisting in clinical decision making and providing the possibility of prevalence and incidence calculations.

The results of agreement in Turkey were superior to the results in Brazil and demonstrate that the profile of the interobserver is significant for the use of SACS ${ }^{\mathrm{TM}}$, which requires training to obtain concordant and consistent results both in clinical practice and in photographs ${ }^{23}$.

Another statistical treatment of this study was the significance level ( $\mathrm{p}$ ), which resulted in $\mathrm{p}<0.001$, representing an extremely significant agreement, proving that the probability of the result is not merely due to chance ${ }^{24,25}$. In other words, the SACS ${ }^{\mathrm{TM}}$ Instrument should have a higher number of studies because of the need to ensure clinical practice to support scientific evidence, since the literature for the SACS ${ }^{\text {TM }}$ Instrument is scarce ${ }^{25}$.

In Brazil, in the city of Criciúma, State of Santa Catarina, 18 patients were analyzed, resulting in $44.5 \%$ of them with peristomal skin lesion, $88.9 \%$ (14) with the occurrence of $\mathrm{L} 2$ and $66.7 \%$ (12) of TV. It was concluded that $\mathrm{SACS}^{\mathrm{TM}}$ is a precise instrument for the classification of the peristomal skin lesion, facilitating the interpretation, detection and 
evolution of the lesion both by health professionals and by the patient himself, being universally recognized that the parameters for classification and topography of the lesion ( $\mathrm{L}$ and T) facilitate its objective evaluation, because it is based on the characteristics of damage of the > skin layers, making its use a standardized language to monitor peristomal lesions, and is an important tool for the interpretation of lesions for nurses, enterostomal therapist and generalist nurses ${ }^{27}$.

The SACS ${ }^{\mathrm{TM}}$ Instrument is a means of communication between professionals. Kapsandoy ${ }^{28}$, a psychologist at Salt Lake City Hospital in the western United States, a leading pediatric care hospital, surveyed 64 parents of children who had an intestinal elimination and feeding ostomy. The objective was to enable parents to evaluate the SACS ${ }^{\mathrm{TM}}$ Instrument and to photograph the presence of the peristomal skin lesion after hospital discharge and send it to professionals through digital media ${ }^{28}$.

It is recognized that injuries can increase rapidly in children, and photos of injuries were sent via the internet and evaluated by generalist nurses. The purpose of sending the photographs is the assessment by an enterostomal therapist nurse whether the lesion could be treated at home with guidelines or if the parents should take the child for consultation with a specialist ${ }^{28}$. A total of 64 generalist nurses and 10 enterostomal therapists collaborated in this study, 1 of them with a certificate of proficiency in the specialty of enterostomal therapy from Wound, Ostomy and Continence Nurses Society (WOCN) ${ }^{28}$.

In order to achieve the objective of the study, parents and generalist nurses were trained with information from the SACS ${ }^{\mathrm{TM}}$ Instrument through photographs of peristomal skin lesions. The evaluation of this training occurred through other photographs of peristomal skin lesions. The recording in the SACS ${ }^{\mathrm{TM}}$ Instrument was evaluated at the same time by the parent, generalist nurse, enterostomal therapist and certified enterostomal therapist, for analysis of the agreement between participants, evidencing the ability to use the SACS $^{\text {TM }}$ Instrument through photographs ${ }^{23,28}$.

At the Salt Lake City Hospital, the photographs were taken by the Department of Information System Security, which used a high-resolution digital camera that allowed immediate image revision. One of the prerogatives for Kapsandoy's study ${ }^{28}$ was that parents had access to the internet and digital cameras, and $97 \%$ of them used the digital camera on their cell phone to send the photos, using fast text communication or e-mails. Parents were trained to capture the image with orientation of lighting, exposure and clean peristomal skin, without collecting system and without skin protection products, writing the initials of the child and the date on a ruler, the words "head" and "feet" on the opposite ends of the ruler, and placing it with the respective information in the respective positions ${ }^{28}$.

Kapsandoy concluded that $80 \%$ of parents and $90 \%$ of generalist nurses found it easy to use the SACS ${ }^{\mathrm{TM}}$ Instrument and to photograph the presence of peristomal skin lesion. The injuries assessed by parents and generalist nurses were classified with more damage to the skin layers than when assessed by enterostomal therapist nurses. It also concluded the feasibility of using $\mathrm{SACS}^{\mathrm{TM}}$ in pediatrics ${ }^{28}$.

The study in Brazil, similarly to Kapsandoy's ${ }^{28}$, presented limitations, since the 41 photographs selected for the analysis of the SACS ${ }^{\mathrm{TM}}$ Instrument were of people with white skin, which does not include the distinction of the skin color of most of the population in our country, which is brown and black, and the classification of erythema in darker skin tones requires more experience from professionals. Another weakness was that the interobserver were inexperienced in the area of clinical practice of stomata.

The Brazilian study identified potentialities for the recording of peristomal skin lesions in health institutions since it presents results on the incidence of skin lesions with the possibility of comparison of data with other studies.

In accordance with the presented studies, the SACS ${ }^{\mathrm{TM}}$ Instrument can contribute to the improvement of the work process, because its dimensions can integrate the pocket material of the nursing professional, has a description of the lesions and their respective photographs, the topographic location and the form of recording Such characteristics reduce the period in the recording of nursing evolution and increase the possibility of standardization of preventive behaviors that promote discussion of the multi-professional team with scientific and efficient communication, contributing to greater visibility of the professional performance of nurses.

\section{CONCLUSION}

The SACS ${ }^{\mathrm{TM}}$ Instrument was translated and adapted into Brazilian Portuguese, certifying reliable results that met the purposes of this study. 
The translation and adaptation of the SACS ${ }^{\mathrm{TM}}$ Instrument are intended for health professionals who assist people with stomata in clinical practice and serve as an example for other studies in which other properties of psychometric measurements with larger samples may test, to constitute more robust scientific evidence in Brazil.

The use of advanced technologies to access the internet or other communication channels with the information of digital photographs makes the specific care occur more quickly, generating safety and comfort for the patient, family members and the multidisciplinary team itself.

Studies are suggested to highlight the use of the SACS ${ }^{\mathrm{TM}}$ Instrument by generalist and enterostomal therapist nurses with more experience in the ostomy area. It is also suggested that the instrument should be a training topic for multi-professional teams and included in the planning of specialization courses in enterostomal therapy and undergraduate courses.
Further research is recommended for the use of the SACS $^{\mathrm{TM}}$ Instrument in skin lesions around tracheostomies, pleurostomies, esophagostomies, jejunostomies, gastrostomies, and digestive fistulas.

Thus, the SACS ${ }^{\mathrm{TM}}$ Instrument is a way to record the evaluation and classification of the peristomal skin by enterostomal therapist and generalist nurses, members of the multi-professional team, adults and parents of children with an ostomy, since they are trained.

\section{AUTHOR'S CONTRIBUTION}

Conceptualization, Silveira NI and Lanza LB; Methodology, Silveira NI and Lanza LB; Investigation, Silveira NI and Lanza LB; Writing - Original Draft, Silveira NI and Lanza LB; Writing - Review and Editing, Silveira NI and Lanza LB; Resources, Silveira NI and Lanza LB; Supervision, Silveira NI and Lanza LB.

\section{REFERENCES}

1. Domanski RC, Chimentão DMN. Prevenção de lesões de pele associadas à umidade. In: Domanski RC, Borges EL. Manual de prevenção de lesões de pele: recomendações baseadas em evidências. Rio de Janeiro (RJ): Rúbio; 2014. 93-150 p.

2. Antonini M e Bosio G, Lucibello L, Pisani F, Fonti A, Scrocca MA, et al. Implementing a validated peristomal skin assessment instrument into clinical practice to facilitate the provision of optimal ostomy care. ECET European Computing Education and Training [Internet]; 2017 [cited 2017 sept 27]. Available at: https://pt.slideshare.net/empoliunited/implementinga-validated-peristomal-skin-assessment-instrument-intoclinical-practice-to-facilitate-the-provision-of-optimalostomy-care-antonini-mario-ecet-2011

3. Salles WJA. Microflora bacteriana e condição imunocelular da região cutânea pericolostomia. In: Paula MAB, Paula PR, Cesaretti IUR. Estomaterapia em foco e o cuidado especializado. São Caetano do Sul (SP): Yendis; 2014. 33-44 p.

4. Taneja C, Netsch D, Rolstad BS, Inglese G, Lamerato L, Oster G. Clinical and economic burden of peristomal skin complications in patients with recent ostomies. J Wound Ostomy Continence Nurs. 2017; 44(4):1-8. https://doi. org/10.1097/WON.0000000000000339

5. Steinhagen E, Colwell J, Cannon LM. Intestinal stomas: postoperative stoma care and peristomal skin complications. Clin Colon Rectal Surg. 2017;30(3):184-92. https://doi. org/10.1055/s-0037-1598159

6. Wound, Ostomy and Continence Nurses Society. Peristomal skin complications: clinical resource guide [Internet]. Mount Laurel
(NJ): WOCNS; 2016 [cited 2017 sept 27]. Available at: http:// www.wocn.org/resource/resmgr/Publications/Peristomal_ Skin_Complication.pdf

7. Paula PR. Complicações precoces e tardias nas estomias intestinais e pele periestomal. In: Santos VLCG, Cesaretti IUR. Assistência em estomaterapia: cuidando de pessoas com estomias. São Paulo (SP): Atheneu; 2015. 311-20 p.

8. Salvadalena G. Incidence of complications of the stoma and peristomal skin among individuals with colostomy, ileostomy and urostomy: a systematic review. J Wound Ostomy Continence Nurs. 2008;35(6):596-607. https://doi. org/10.1097/01.WON.0000341473.86932.89

9. Beitz J, Gerlach M, Ginsburg P, Ho M, McCann E, Schafer $\checkmark$, et al. Content validation of a standardized algorithm for ostomy care. Ostomy Wound Manage. 2010;56(10):22-38.

10. Bosio G, Pisani F, Fonti A, Scrocca A, Morandell C, Anselmi $L$, et al. Studio osservazionale multicentrico sulle alterazioni cutanee post-enterostomie (SACS): classificazione delle alterazioni peristomali. G Chir. 2006;27(6-7):251-4.

11. Bosio G, Pisani F, Lucibello L, Fonti A, Scrocca A, Morandell C, et al. A proposal for classifying peristomal skin disorders: results of a multicenter observational study. Ostomy Wound Manage. 2007;53(9):38-43.

12. ConvaTec. The SACSTM Instrument. Oklahoma City (OK): ConvaTec; 2017 [cited 2019 jan 15]. Available at: https:// www.convatec.com/ostomy/sacs-instrument/ 
13. Beaton DE, Bombardier C, Guillemin F, Ferraz MB. Guidelines for the Process of Cross-Cultural adaptation of self-report Measures. Spine. 2000;15(24):3186-91. https:// doi.org/10.1097/00007632-200012150-00014

14. Polit DF, Beck CT, Hungler BP. Fundamentos de pesquisa em enfermagem: métodos, avaliação e utilização. 7 ed. Porto Alegre (RS): Armed; 2004; 466 p.

15. Souto MVL, Além AOFG, Brito, AMS, Bernardo C. Conceitos de língua estrangeira, língua segunda, língua adicional, língua de herança, língua franca e língua transnacional. Revista Philologus. 2014;20(60)(1 Suppl):890-900.

16. Gimenez T, Kadri MSE, Calvo LCS, Siqueira DSP, Porfirio L. Inglês como língua franca: desenvolvimentos recentes. Rev Bras Linguist Apl. 2015;15(3):593-619. https://doi. org/10.1590/1984-639820157010

17. Alexandre NMC, Coluci MZO. Validade de conteúdo nos processos de construção e adaptação de instrumentos de medidas. Ciênc Saúde Coletiva. 2011;16(7):3061-8. https:// doi.org/10.1590/S1413-81232011000800006

18. Landis JR, Koch GG. An application of hierarchical Kappatype statistics in the assessment of majority agreement among multiple observers. Biometrics. 1977;33(2):363-74. https://doi.org/10.2307/2529786

19. Margotto PR. Índice de concordância intra e entreobservadores: Estatística K/coeficiente (tau) de Kendall [Internet]; 2018 [cited 2019 sept 13]. Available at: http:// paulomargotto.com.br/indice-de-concordancia-intra-eentre-observadores-estatistica-k-coeficiente-tau-de-kendall/

20. Faculdade de Medicina do Porto. Métodos para Estimação de reprodutividade de medidas: estatística Kappa (K) [Internet]; 2019 [cited 2019 sept 13]. Available at: https:// users.med.up.pt/ joakim/intromed/estatisticakappa.htm
21. Ferreira JC1, Patino CM. O que realmente significa o valor-p? J Bras Pneumol. 2015;41(5):485-48._https://doi.org/10.1590/ S1806-37132015000000215

22. Karadağ A, Baykara ZG, Korkut H, Çelik B. Adaptation of the ostomy adjustment inventory into Turkish Language. Turk J Surg. 2011;27(4):206-11.

23. Gomes PC. A fotografia na academia: de formadora de imaginários coletivos a fonte de pesquisas. Londrina (SP): Midiograf; 2015; 256 p.

24. Heale R, Twycross A. Validity and reliability in quantitative studies. Evid Based Nurs. 2015;18(3):66-7. https://doi. org/10.1136/eb-2015-102129

25. Souza AC, Alexandre NMC, Guirardello EB. Propriedades psicométricas na avaliação de instrumentos: avaliação da confiabilidade e da validade. Epidemiol Serv Saúde. 2017;26(3):649-59. https://doi.org/10.5123/s167949742017000300022

26. Ay A, Bulut $\mathrm{H}$. Assessing the Validity and Reliability of the Peristomal Skin Lesion Assessment Instrument Adapted for Use in Turkey. Ostomy Wound Manage. 2015;61(8):26-34.

27. Schwalm MT, de Carvalho $P$, de Farias BM, Belmiro A, Zimmermann K, Ceretta LB. Perfil da pessoa estomizada com lesão periestomal e avaliação da lesão com SACS. Anais do III Simpósio Internacional Norte e Nordeste de Estomaterapia, Maceió (AL): SOBEST; 2014 [cited 2019 sept 13]. Available at: www.sobest.org.br/anais-arquivos/800833.html

28. Kapsandoy SC. Feasibility and psychometric evaluation of the Studio Alterazioni Cutanee Stomali (SACS ${ }^{\mathrm{TM}}$ ) instrument for assessment of peristomal skin lesions in children [dissertação]. Utah (EUA): College of Nursing, University of Utah; 2015. 